\title{
OPPORTUNITIES FOR ELECTRIC VEHICLE FAST CHARGING NETWORKS IN NORTHERN REGIONS USING SMART CHARGING
}

\author{
Aivars Rubenis ${ }^{1}$, Dainis Tropins ${ }^{2}$, Leslie R. Adrian ${ }^{3}$ \\ ${ }^{1}$ Latvia University of Life Sciences and Technologies, Latvia; ${ }^{2}$ EMI Electronics, Latvia; \\ ${ }^{3}$ Riga Technical University, Latvia \\ aivars.rubenis@transfoelectric.com,dainis@emi-electronics.lv, leslie.adrian@rtu.lv
}

\begin{abstract}
The article examines the possibilities of charging electric vehicles from renewable resources in Latvia. Electric vehicles (EV) have been recognized as a way to decrease $\mathrm{CO} 2$ emissions in the transportation sector. Still, the real benefit of EV's depends on the source of the energy. Solar energy has been established to become a viable source for environmentally friendly energy as the costs of solar panels have been decreasing. However, in northern areas the amount of solar energy is limited during wintertime, which complicates using solar energy as the only energy source. This article models two possible operational scenarios for energy consumption for EV charging, based on empirical data from charging station use in Latvia - one prioritizing energy security, the other - use of locally produced solar energy. The article then evaluates how both scenarios perform, by looking at the capacity for energy production from photovoltaics obtained from solar radiation data in Latvia and combining with an option of energy storage in batteries. It then assesses the costs for solar energy comparing with the energy price in the grid, to estimate the economic benefits of using solar energy for EV charging. The results of the research show that for northern regions like Latvia solar energy can be effectively used to bring down the energy costs by $31 \%$ compared with the standard scenario, with the algorithm preferring local energy being more cost-efficient at the same grid connection level, but the security prioritizing algorithm performing better altogether, by allowing larger grid connection power level decrease.
\end{abstract}

Keywords: electric vehicles, solar energy, PV.

\section{Introduction}

The IPCC special report on the impacts of global warming of $1.5^{\circ} \mathrm{C}$ above pre-industrial level [1] has once again stressed the importance of the need to decrease $\mathrm{CO} 2$ emissions. Transportation sector currently is the main sector in the European Union, where greenhouse gas (GHG) emissions are still growing - during the last seven years GHG from transport have increased by $18 \%$ in the EU [2]. Electric vehicles are believed to be one of the most potential ways how to decrease GHG emissions in transportation, however, the actual impact greatly depends on the origin of the electricity. On average $\mathrm{CO} 2$ emissions for electricity production have decreased significantly in the European Union, down from $523.6 \mathrm{~g} \mathrm{CO} \cdot \mathrm{kWh}^{-1}$ in 2009 to $295.8 \mathrm{CO} 2 \cdot \mathrm{kWh}^{-1}$ in 2016 [3], which largely has been achieved by increasing renewable energy sources in energy production. Also in Latvia the goals have been set to reach $40 \%$ renewable energy in overall energy mix by 2020 [4]. There is, however, a possibility to increase the benefits of renewable energy in the transportation sector, by using solar energy directly for electric vehicle charging.

There have been several studies on possibilities of using solar energy in Latvia starting already from the end of the last century [5], however, until now, it was considered that solar energy is rather costly [6] and in northern areas, like Latvia, the amount of solar energy is limited during wintertime, which complicates using solar energy as the only energy source [7]. As the price of solar panels has been decreasing significantly during the last 10 years, the economy of solar energy generation is gradually becoming more feasible in Latvia, although governmental support would still be needed [8].

So far there has not been specific analysis of using renewable energy for electric vehicle charging in Latvia. This article is a continuation of the research presented in [9], where the model was developed to help evaluate the potential for renewable energy and storage systems for use in the Latvian national electric vehicle fast charging network. The aim of this article is to further demonstrate not only the technical possibilities, but also economic feasibility of using solar energy for EV charging by comparing two algorithms of energy flow management to evaluate the financial performance of each.

The scope of this article is limited to the energy costs and does not evaluate the capital expenses of the solar and energy storage system installations, nor operational costs for their support during lifetime. 


\section{Materials and methods}

The model for energy flows is structured in the following blocks:
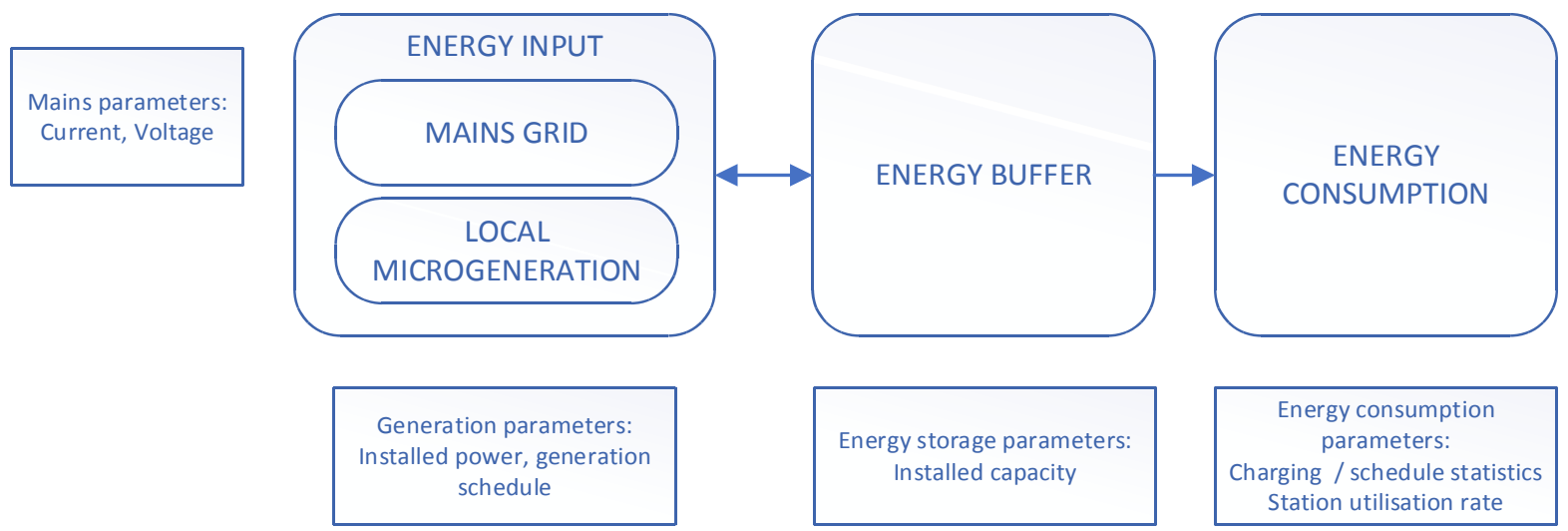

Fig. 1. General structure of model

Annual solar irradiation level ranges from 675 to $1100 \mathrm{kWh} \cdot \mathrm{m}^{-2}$ in Latvia [10], however, because of the intermittent nature of solar radiation, the exclusive use of solar energy for EV charging is challenging, requiring energy storage facilities. Detailed hourly and daily solar radiation information for locations in Europe is available from the JRC Photovoltaic geographical information system [11], which was used to develop a model for solar energy generation simulation in [12] using microcrystalline solar cells. The energy production distribution during a year is displayed in Table 1 .

Table 1

Energy production distribution during a year in Latvia

\begin{tabular}{|c|c|c|c|c|c|c|c|c|c|c|c|c|c|}
\hline Month & Jan & Feb & Mar & April & May & June & July & Aug & Sep & Oct & Nov & Dec & Total \\
\hline $\begin{array}{c}\text { Energy } \\
\text { distribution, } \\
\%\end{array}$ & 2 & 5 & 9 & 12 & 14 & 14 & 14 & 12 & 9 & 5 & 2 & 1 & 100 \\
\hline
\end{tabular}

A model for energy storage and use for electric vehicle fast charging stations was developed in [9], using the current average charging schedules in the Latvian electric vehicle fast charging network during 2018.At the current charging station utilisation rate in the Latvian fast charging network, $93 \%$ of all charging stations could be successfully covered by the algorithm where the general priorities are:

1. To provide maximum energy security [13] for the clients, the battery always has to be charged as much as possible;

2. Locally generated power should be used locally, for EV charging and battery charging.

This algorithm however is not optimal from the financial point of view, as it does not prioritize the locally generated energy for storage in batteries. Thus the portion of the energy generated in PV array will be sold to the grid and then bought back, which adds additional costs for the transmission and distribution fees as well as the green energy tax, which has to be paid in Latvia for all energy even if one is producing green energy oneself [14].

Therefore, in this paper, results of two algorithms will be compared:

1. Energy security algorithm, which prioritizes the uninterrupted availability of energy sources, as described in detail in [9]. Cost prioritising algorithm described here. The cost prioritising algorithm ranks use of locally produced PV power first, in order to avoid the transmission and distribution fees, which in Latvia are $41.76 \mathrm{EUR} \cdot \mathrm{MWh}^{-1}$ [15] and tax on renewable energy 14.63 EUR $\cdot \mathrm{MWh}^{-1}$, The cost prioritising algorithm

The algorithm could be further improved by adding some very basic arbitrage options for energy price fluctuations. The Nord Pool energy price data from 2018 [16] (Fig. 2) display the daily average energy price difference of $30 \mathrm{EUR} \cdot \mathrm{MWh}^{-1}$ from $4 \mathrm{AM}$ to $8 \mathrm{AM}$, which would allow additional income from the storage system. 


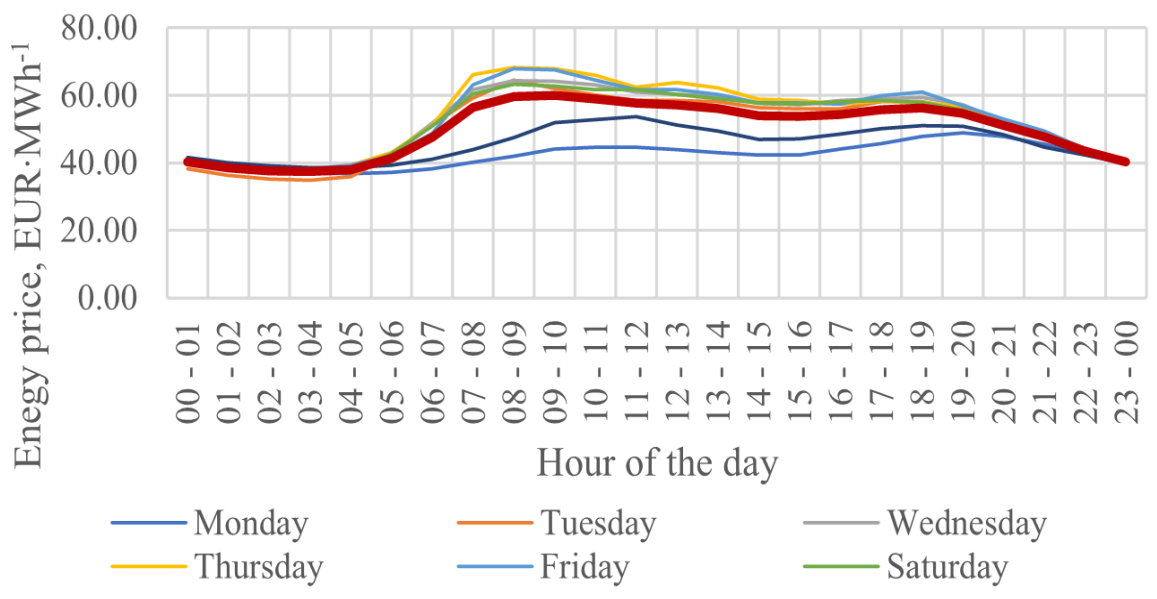

Fig. 2. Average cost of transmission and distribution per $\mathrm{kWh}$ charged in Latvian national fast charging network

However, when taking into account the full costs, it is clear that total distribution costs and taxes 68.56 EUR $\cdot \mathrm{MWh}^{-1}$ are twice as much as average price difference.

This does not necessarily mean that price arbitrage is not possible; however, it will be not as simple as daily purchase and sale, therefore it will fall beyond the scope of this article.

\section{Results and discussion}

Two models were run on the same data set of the charging scenario, which was the same scenario used in [9]. The charging scenario was based on a fast charging station with $4 \%$ utilisation, which represents $93 \%$ of all charging stations in Latvia, and grid connection decreased to $50 \mathrm{~A}$ from $80 \mathrm{~A}$, which would normally be used for fast charging station installation. It also includes $2.24 \mathrm{~kW}$ solar charger, as per single car Solisco charge port specification [17].

The simulation results displayed in Table 2 show the distribution of outcomes on the scale from 0 to 3 , based on severity of failure, where 0 represents that there was enough energy to fully charge the car and 3 meaning critical failure, when the energy from all energy sources was not sufficient to fully cover the requirements and the car would have to be charged slower.

Table 2

Variable energy transmission and distribution costs for rapid charging station in Latvia

\begin{tabular}{|c|c|c|c|c|c|c|c|c|}
\hline Simulation outcomes & \multicolumn{3}{|c|}{ Priority safety, \% } & \multicolumn{3}{c|}{ Priority local energy use, \% } \\
\hline Installed battery storage, Wh & 0 & 1 & 2 & 3 & 0 & 1 & 2 & 3 \\
\hline 0 & 49.8 & - & & 50.2 & 49.8 & - & - & 50.2 \\
\hline 2000 & 49.8 & - & 16.9 & 33.3 & 54.6 & 0.1 & 3.0 & 42.3 \\
\hline 4000 & 49.8 & - & 35.0 & 15.2 & 56.6 & 0.1 & 6.1 & 37.2 \\
\hline 6000 & 49.7 & 0.1 & 44.1 & 6.1 & 57.1 & 0.3 & 9.4 & 33.2 \\
\hline 8000 & 49.8 & - & 48.7 & 1.4 & 57.1 & 0.3 & 12.9 & 29.7 \\
\hline 10000 & 49.8 & - & 50.2 & - & 57.1 & 0.4 & 16.4 & 26.1 \\
\hline 12000 & 49.8 & - & 50.2 & - & 57.0 & 0.5 & 19.6 & 22.9 \\
\hline 14000 & 49.8 & - & 50.2 & - & 57.0 & 0.5 & 22.6 & 19.9 \\
\hline 16000 & 49.8 & - & 50.2 & - & 56.9 & 0.6 & 25.3 & 17.2 \\
\hline 18000 & 49.8 & - & 50.2 & - & 56.8 & 0.7 & 28.4 & 14.1 \\
\hline 20000 & 49.8 & - & 50.2 & - & 56.7 & 0.8 & 31.0 & 11.5 \\
\hline 22000 & 49.8 & - & 50.2 & - & 56.7 & 0.8 & 32.6 & 9.9 \\
\hline 24000 & 49.8 & - & 50.2 & - & 56.7 & 0.8 & 35.4 & 7.1 \\
\hline
\end{tabular}


The differences between both algorithms were quite large. With the safety priority algorithm, the critical failure was reached if the storage amount was less than $8 \mathrm{kWh}$, while with priority of local energy use the critical failure happened $7 \%$ of the time even with the full $24 \mathrm{kWh}$ battery pack.

Looking at energy distribution between the two algorithms, the two most noticeable differences are that in the local use scenario there is no energy flow into the grid (i.e. all PV energy has been used locally either stored in batteries or used directly to charge EV) and that there is energy shortage of $0.11 \mathrm{MWh}$ (total energy needed for EV charging has been 15.2 MWh, as can be seen in the security scenario).

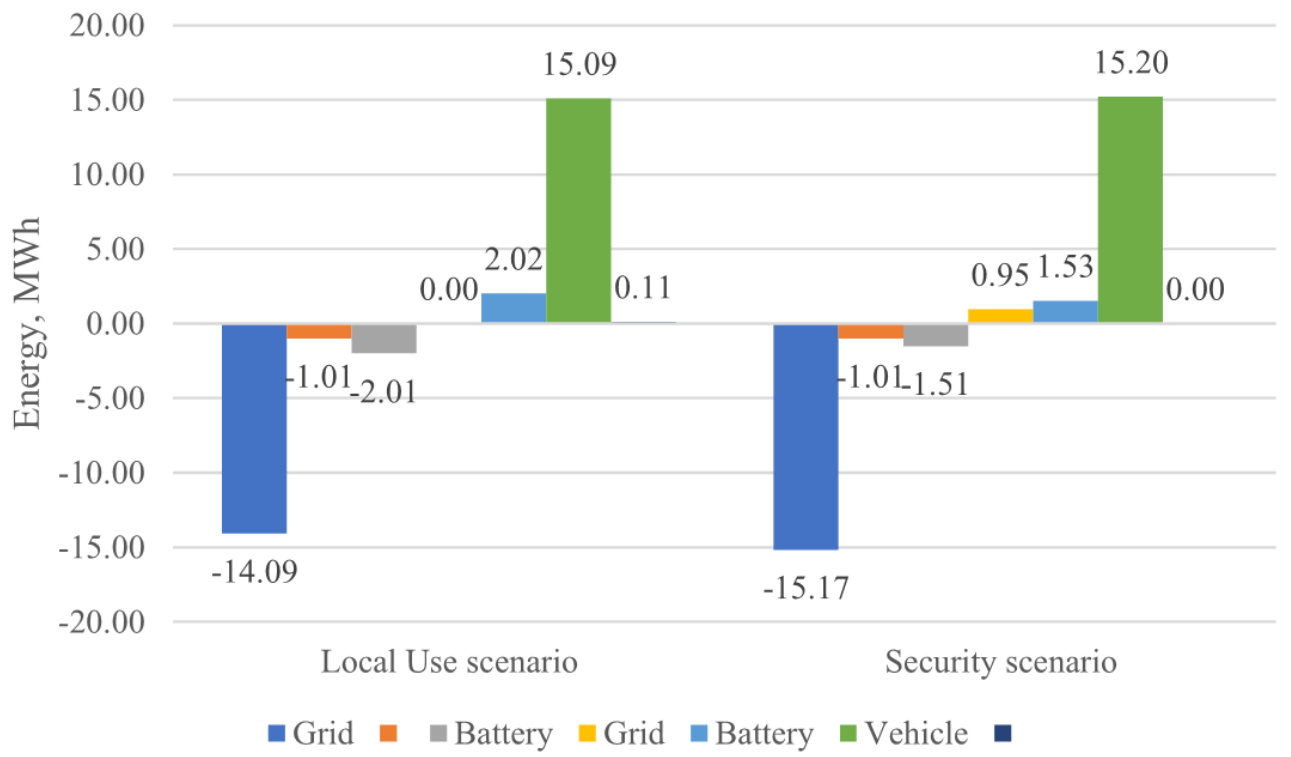

Fig. 3. Energy sources and distributions in two operation algorithms

Table 3 demonstrates the cost and income calculations for a year based on four scenarios. Baseline scenario demonstrates the current energy costs for fast charging stations in the Latvian national electric vehicle charging network without PV or energy storage. The three remaining scenarios show the effect of introduction of PV and energy storage with both priority algorithms and different grid connection levels. The variable energy costs are calculated using average Nord Pool spot prices in December 2018 [14].

The calculations demonstrate that PV and energy storage system using local energy decreases the energy costs by 737 EUR compared to the current unassisted fast charging station with $80 \mathrm{~A}$ grid connection. However, the energy security scenario allows further decrease of grid connection. As demonstrated in [9], the grid connection can be brought down to 32 A without a risk of critical failures getting over $0.1 \%$. In this case, the costs can be decreased further by $1038 \mathrm{EUR}$, or by $31 \%$ compared with the 80 A connection.

Nevertheless, since at equal connection the local energy algorithm provides greater return, further research will be carried out in two directions.

- The first direction is analysis on how the increase in PV generation would affect the economic effect. For complete understanding of it, initial investment costs would play crucial role;

- The second direction is more detailed charging scenario analysis under various locations. The basis for the charging schedules used in [9] was originally attained analysing general charging event distribution in Latvia [20]. It will have to be analysed in more detail whether there are significant differences between charging station use for heavily used stations, like Riga, and in charging stations in the countryside.

These differences might affect the performance of each algorithm, so that electricity grid connection can be brought down even more using locally produced energy. 


\section{Energy costs for a year for rapid charging station in Latvia} under different energy flow algorithms

\begin{tabular}{|c|c|c|c|c|c|c|c|c|c|}
\hline \multirow[b]{2}{*}{ Scenario } & \multirow[b]{2}{*}{$\begin{array}{c}\text { Grid } \\
\text { connect } \\
\text { ion, A }\end{array}$} & \multicolumn{3}{|c|}{ Fixed costs } & \multicolumn{5}{|c|}{ Variable Costs } \\
\hline & & $\begin{array}{c}\text { Distributio } \\
\text { n costs, } \\
\text { EUR } \cdot A^{-1} \\
{[15]}\end{array}$ & 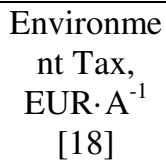 & $\begin{array}{l}\text { Total, } \\
\text { EUR }\end{array}$ & $\begin{array}{c}\text { Energy } \\
\text { from grid, } \\
\mathrm{kWh}\end{array}$ & $\begin{array}{c}\text { Price, } \\
\text { EUR· } \\
\mathrm{kWh}^{-1} \\
{[16]}\end{array}$ & $\begin{array}{c}\text { Distribution } \\
\text { costs, } \\
\text { EUR } \cdot \mathrm{kWh}^{-1} \\
{[15]}\end{array}$ & \begin{tabular}{|c} 
Environment \\
Tax, \\
EUR $\cdot \mathrm{kWh}^{-1}$ \\
{$[19]$}
\end{tabular} & $\begin{array}{l}\text { Total, } \\
\text { EUR }\end{array}$ \\
\hline Baseline & 80 & 14.2 & 6.28 & 1638.4 & 15203.20 & 0.0536 & 0.04176 & 0.01463 & 1672.50 \\
\hline $\begin{array}{l}\text { Scenario: } \\
\text { secure }\end{array}$ & 50 & 14.2 & 6.28 & 1024.0 & 15170.49 & 0.0536 & 0.04176 & 0.01463 & 1668.91 \\
\hline $\begin{array}{c}\text { Scenario: } \\
\text { local }\end{array}$ & 50 & 14.2 & 6.28 & 1024.0 & 14085.72 & 0.0536 & 0.04176 & 0.01463 & 1549.57 \\
\hline $\begin{array}{l}\text { Scenario: } \\
\text { secure }\end{array}$ & 32 & 14.2 & 6.28 & 655.4 & 15153.28 & 0.0536 & 0.04176 & 0.01463 & 1667.01 \\
\hline
\end{tabular}

\begin{tabular}{|c|c|c|c|c|c|c|c|}
\hline & & \multicolumn{3}{|c|}{ Income } & \multicolumn{3}{|c|}{ Total costs } \\
\cline { 3 - 8 } Scenario & $\begin{array}{c}\text { Grid } \\
\text { connect } \\
\text { ion, A }\end{array}$ & $\begin{array}{c}\text { Energy } \\
\text { sold to } \\
\text { grid, kWh }\end{array}$ & $\begin{array}{c}\text { Price, } \\
\text { EUR·kWh } \\
1\end{array}$ & $\begin{array}{c}\text { Total } \\
\text { income, } \\
\text { EUR }\end{array}$ & $\begin{array}{c}\text { Total costs, } \\
\text { EUR }\end{array}$ & $\begin{array}{c}\text { Price of } \\
\text { a kWh, } \\
\text { EUR } \\
\text { compared } \\
\text { with } \\
\text { baseline, } \\
\text { EUR }\end{array}$ \\
\hline Baseline & 80 & 0 & 0.0536 & 0 & 3310.90 & 0.22 & 0.00 \\
\hline $\begin{array}{c}\text { Scenario: } \\
\text { secure }\end{array}$ & 50 & 951.32 & 0.0536 & 51.01 & 2641.90 & 0.17 & 669.01 \\
\hline $\begin{array}{c}\text { Scenario: } \\
\text { local }\end{array}$ & 50 & 0 & 0.0536 & 0 & 2573.57 & 0.17 & 737.33 \\
\hline $\begin{array}{c}\text { Scenario: } \\
\text { secure }\end{array}$ & 32 & 936.29 & 0.0536 & 50.20 & 2272.17 & 0.15 & 1038.74 \\
\hline
\end{tabular}

\section{Conclusions}

The research analysed two different algorithms for EV charging station operation, in order to assess the performance of each for savings of energy costs:

1. Both algorithms allowed significant energy cost savings. At the same power level, the algorithm maximising local energy performs slightly better, allowing $25 \%$ cost decrease compared to the algorithm which prioritizes energy security, which allows only $22 \%$ cost decrease.

2. However, the energy security algorithm allows larger decrease in the main grids power level, thus totally allowing $31 \%$ cost decrease.

2. Further research is needed to examine whether the performance for both algorithms will be the same under different scenarios, like increase of PV generation power or changes in charging station use, e.g. whether it depends on their location.

\section{Acknowledgements}

This paper has been published within the research project "Research on effect of electric vehicle charging on electricity grid and on possibilities to use them to improve the energy network and load distribution" carried out within a grant program by the European Regional Development Fund for general industrial research and for projects dealing with new product and technology developments Project number: 1.2.1.1./16/A/008.

\section{References}

[1] Intergovernmental Panel on Climate Change. IPCC special report on the impacts of global warming of $1.5^{\circ} \mathrm{C}$ - Summary for policy makers, 2018.

[2] European Environment Agency. Annual European Union greenhouse gas inventory 1990-2016 and inventory report 2018 Submission to the UNFCCC Secretariat. 2018. 
[3] European Environment Agency Overview of electricity production and use in Europe. 2018. [online] [28.01.2019] Available at: https://www.eea.europa.eu/data-and-maps/indicators/ overview-of-the-electricity-production-2/assessment-4.

[4] Cabinet of Ministers of Republic of Latvia On Energy Development Guidelines (Par Energèetikas attīstības pamatnostādnēm 2016-2020. gadam). Cabinet of Ministers of Republic of Latvia, 2016.

[5] Shipkovs P., Kashkarova G., Shipkovs M. Renewable energy utilization in Latvia. Renewable Energy, vol. 16, no. 1-4 1999, pp. 1241-1244.

[6] Shipkovs P., Kashkarova G., Lebedeva K., et al. Potential and analysis of grid integrated renewables in Latvia. Energy Procedia, vol. 57, 2014, pp. 735-744.

[7] Dusonchet L., Telaretti E. Economic analysis of different supporting policies for the production of electrical energy by solar photovoltaics in eastern European Union countries. Energy Policy, vol. 38, no. 8 2010, pp. 4011-4020.

[8] Rozentale L., Lauka D., Blumberga D. Accelerating power generation with solar panels. Case in Latvia. Energy Procedia, vol. 147, 2018, pp. 600-606.

[9] Rubenis A., Tropiņš D., Zvirbule A. Development of model for increasing electric vehicle charging capacity with limited available grid power. Engineering for Rural Development, 2019.

[10] Udrene L., Bazbauers G. Role of Vehicle-to-grid Systems for Electric Load Shifting and Integration of Intermittent Sources in Latvian Power System. Energy Procedia, vol. 72, 2015, pp. 156-162.

[11]JRC European Comission Photovoltaic Geographical Information System (PVGIS). Joint Research Centre - Institute for Energy and Transport, 2014, p. 10.

[12] Rubenis A., Adrian L. R. Determining energy storage amount for development of novel microgrid energy flow optimization system with photovoltaic energy generation. Energy Procedia, vol. 147, 2018, pp. 428-437.

[13] International Energy Agency What is energy security?. [online] [02.02.2019] Available at: https://www.iea.org/topics/energysecurity/whatisenergysecurity/.

[14]Electricity Market Law (Elektroenergijas tirgus likums). Riga: Saeima, 2016.

[15] Sadales Tikls Electricity distribution differential tariffs., vol. 2016,. Riga, 2016.

[16] Nord Pool Historical Market Data. 2019. [online] [02.02.2019] Available at: https://www.nordpoolgroup.com/historical-market-data/.

[17] Solisco Solisco EV-Ports. 2019. [online] [26.01.2019] Available at: https://solisco.co.uk/ configure-stage- $1 /$.

[18] Pubic Utilities Commission of Latvia Par jaudas komponentēm no 2018.gada 1.jūlija (On power component)., no. 202. Latvia: Pubic Utilities Commission of Latvia, 2018, pp. 8-9.

[19] Elektrum SIA Obligātā iepirkuma un jaudas komponentes (Mandatory procurement and power components). 2018. [online] [01.02.2019] Available at: https://www.elektrum.lv/lv/uznemumam/ elektroenergija/obligata-iepirkuma-un-jaudas-komponentes-/.

[20] Rubenis A., Laizāns A., Zvirbule A. Latvian Electric Vehicle fast charging infrastructure: results of the first year of operation. Energy Procedia, 2019. 